\title{
Semi-solid fermentation of nopal (Opuntia spp) for use as an animal protein supplement
}

\author{
Arnoldo Flores Hernández ${ }^{1}$ \\ Fco. Javier Macías Rodríguez ${ }^{2 *}$ \\ Cesar Meza Herrera ${ }^{1}$ \\ Gabriel García Herrera ${ }^{1}$ \\ Oscar Esquivel Arriaga ${ }^{1}$ \\ Jorge Ortiz Salazar ${ }^{1}$ \\ Cristóbal Hernández Bautista ${ }^{1}$
}

\begin{abstract}
In order to mitigate the severe shortage of forage and the high cost of protein sources during the winter drought in northern Mexico, new technology aimed at enriching the protein content of "nopal" (Opuntia spp) was developed. This perennial crop is highly appreciated as a forage supplement in drought conditions due to its high water content (80-90\%), although its low protein content (4-6\%) limits its nutritional value. The technology is based on semi-solid fermentation of 1-year-old spineless cladodes as substrate by using Saccharomyces cerevisiae (1\%) as yeast and adding urea ( $1 \%)$ and ammonium sulfate $(0.1 \%)$ as protein sources. Fermentation occurs under aerobic conditions at a temperature of $25 \pm 3^{\circ} \mathrm{C}$ and acid $\mathrm{pH}$ of $4.35 \pm 0.04$ during a 10-hour process with 8 motion intervals, namely 45 -minute motions and 20-minute rests. Treatments were statistically analyzed using the SAS program (9.1)/GLM procedure and Tukey's multiple comparison test in a completely randomized design with three replicates. Results showed a significant increase in the crude protein content of fermented

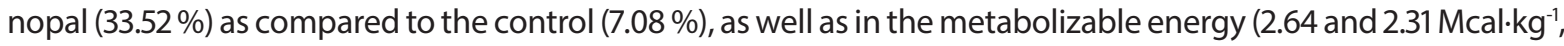
respectively). As a result of fermentation, non-fibrous carbohydrates were reduced significantly (55.03 vs 25.77 $\%$ for the control and fermented nopal, respectively). Dry matter showed no significant effect ( $8.0 \%$ average). Crude protein obtained in fermented nopal (30\%) is higher than that reported for alfalfa (25.8\%), but it is lower when compared on a dry matter basis ( 8 vs $30 \%$ for nopal and alfalfa, respectively). However, in terms of water consumption and yield, nopal is superior to alfalfa. Later tests indicated that when used as a forage supplement in feeding bovines (both for milk and meat purposes) as well as sheep and goats, fermented nopal improved the body condition and increased their weight as compared to conventional diets.
\end{abstract}

Keywords: Protein supplement, forage, animal feeding.

\section{Fermentación semisólida del nopal (Opuntia spp) para su uso como complemento proteico animal}

\section{Resumen}

En atención a la grave escasez de forraje y el alto costo de fuentes proteicas en la época de sequía e invernal en el norte de México, se generó la tecnología de enriquecimiento proteico del nopal (Opuntia spp), cultivo perenne que resulta un valioso auxiliar forrajero durante la sequía por su alto contenido de agua (80-90\%) aunque su bajo valor proteico (4-6 \%) limita su uso. La tecnología se basa en la fermentación semisólida de fracciones de penca anual de nopal sin espinas (sustrato) con la adición de la levadura Saccharomyces cerevisiae (1\%) y con las fuentes de nitrógeno: Urea (1\%) y Sulfato de Amonio ( $0.1 \%)$, en condiciones aeróbicas,

'Universidad Autónoma Chapingo, (URUZA), km 40 carretera Gómez Palacio- Chihuahua., C.P. 35230. Bermejillo, Dgo. México.

2Universidad Autónoma Chapingo, (CRUCEN), km 20.5 carretera Zacatecas-Fresnillo, C.P. 98100. Morelos, Zac. México.

*Corresponding author: soffcogerbre@gmail.com

Received: February 1, 2019.

Accepted: June 18, 2019. 
temperatura $\left(25 \pm 3^{\circ} \mathrm{C}\right)$ y $\mathrm{pH}$ ácido $(4.35 \pm 0.04)$, en la máquina que realiza el proceso durante 10 horas con 8 intervalos de: Movimiento ( $45 \mathrm{~min}$ ) y Reposo (30 min). Esta técnica fue analizada estadísticamente con el procedimiento GLM del Programa SAS (9.1) y la prueba de comparación de medias de Tukey, en un diseño completamente al azar con tres repeticiones del tratamiento: Nopal picado sin proceso (Testigo) y Nopal picado fermentado. Los resultados muestran un incremento significativo en el contenido de proteína cruda de 7.08 \% (Testigo) a $33.52 \%$ (Nopal Fermentado) y Energía Metabolizable de 2.31 a $2.64 \mathrm{Mcal}^{\mathrm{k}} \mathrm{kg}^{-1}$ respectivamente. Mientras los carbohidratos no fibrosos se redujeron significativamente de $55.03 \%$ (Testigo) a 25.77 \% (Nopal Fermentado), por efecto de la fermentación. La materia seca no presentó diferencia significativa ( $8.0 \%$. promedio). El porcentaje obtenido de proteína cruda en nopal fermentado comparado con la alfalfa (25.8\%) resulta superior, pero no es así cuando esta proteína se basa en el peso seco del nopal (8\%) respecto al de la alfalfa (30\%), pero las características del consumo de agua y rendimiento del nopal lo hacen muy superior a la alfalfa. En pruebas posteriores se identificó que el consumo de nopal fermentado tipo complemento alimenticio en ganado mayor (bovino lechero y de engorda) y menor (ovinos y caprinos) mejoró significativamente la condición corporal e incrementó el peso vivo respecto a la dieta tradicional que otorgó el productor.

Palabras clave: Complemento proteico, forraje, alimentación animal.

\section{Introduction}

Nopal (Opuntia spp), as it is called in Mexico, is a typical plant in virtually all Mexican flora, as well as being a symbol of the Mexican people that gives them identity, in addition to corn and agave. Nopal has been a staple food throughout its history and has played an important role in cultural development, as in the case of the Chichimeca groups' settlements in the north-central region of the country. On the other hand, it is known for its use as food, medicine, drink, etc. But the economic importance of nopal as fodder was not recognized during the Spanish colonial period, or even after the Independence struggle. However, there are records of the use of nopal as fodder during the colonial and post-independence periods indicating that it was used as animal feed, especially in the arid and semi-arid areas of the north of the country. It is mentioned that its use as fodder increased at the beginning of the 17th century with the arrival of cattle in semi-arid areas due to the decrease in grasslands, which forced livestock producers to harvest the nopal cladodes, singe them to remove the spines and use them as fodder, mainly during periods of very low rainfall (Anaya, 2003).

In Mexico, the nopal is recognized as consisting of 377 species of the genus Opuntia of the family Cactaceae, of which approximately $50 \%$ of them are used in an artisanal or industrial way; the rest of

\section{Introducción}

El nopal (Opuntia spp), así llamado en México, es una planta típica prácticamente en toda la flora mexicana, además de ser el símbolo del pueblo mexicano que le da identidad, así como el maíz y el agave. El nopal ha sido un alimento básico a través de su historia y ha jugado un papel importante en el desarrollo cultural, como fueron los acontecimientos de asentamientos humanos como los grupos chichimecas de la región centro norte del país. Por otra parte, se conoce como alimento, medicina, bebida, etc. Pero la importancia económica del nopal como forraje no se reconocía durante la colonia española, inclusive, después de la lucha de Independencia. Existen registros del uso del nopal como forraje durante las épocas coloniales y posteriores a la independencia que indican que era empleado como alimento para animales, especialmente en las zonas áridas y semiáridas del norte del país, se menciona que su uso como forraje se incrementó a inicios del siglo XVII con la llegada de ganado a las áreas semiáridas debido a la disminución de pastizales, situación que obligó a los productores de ganado a cosechar las pencas de nopal, chamuscarlas para eliminar las espinas y usarlas como alimento forrajero, principalmente durante las épocas de muy escasa precipitación (Anaya, 2003). 
the species are found in the wild, being used only by the collection method without proper utilization management. It is estimated that only 15 species are used as fodder. Internationally, the main producer is Brazil, followed by South Africa, Mexico and Tunisia. In Mexico, the main producer states, in order of importance, are: Oaxaca, Jalisco, San Luis Potosí, Zacatecas, Puebla, Mexico, Hidalgo and Morelos. It is estimated that Mexico has a nopal-growing area of approximately $150000 \mathrm{ha}$, with average yields being around $20.5 \mathrm{t} \cdot \mathrm{ha}^{-1}$ although in some cases they reach up to 50 tha $^{-1}$ (Saravia, $\mathrm{n} / \mathrm{d}$ ).

It is estimated that $66.2 \%$ of Mexico's area has an arid or semi-arid climate, with the country's north central region being the one that presents these conditions. The main states that are in this situation are Aguascalientes, Baja California, Baja California Sur, Coahuila, Chihuahua, Durango, Guanajuato, Nuevo León, Querétaro, San Luis Potosí, Sonora, Tamaulipas and Zacatecas. The peculiarity is that more than $50 \%$ of its territory has the characteristics of an arid and semi-arid climate (Medina, Ruiz, \& Bravo, 2004, INEGI, 2005).

In arid and semi-arid areas, it is common for feed shortage periods to occur for animals, so livestock farmers resort to cultivated fodder plants in order to maintain the productivity of the livestock system. In these regions, fodder production is restricted due to the limited availability of water and low soil fertility. In this situation, nopal acquires great value as livestock feed, due to its great capacity to establish, reproduce and produce sufficient fodder in conditions of low rainfall and low soil fertility, thereby enabling livestock to survive (de la Rosa \& Santana, 1998; Flores \& Aranda, 1997).

In the semi-arid areas of northern Mexico, the animal feed situation in the drought months is critical due to the limited availability of forage and the high cost of protein sources, which makes the proper use of supplements impossible and thus the minimum nutrient requirements of these animals are not met (Murillo et al., 2009). Nopal (Opuntia spp) in this difficult period is widely used for its high water content (70 to $90 \%$ ) despite its low protein value (2.7 to 8.8 \%) (López, Fuentes, \& Rodríguez, 2003). The advantages of growing spineless nopal for its cladodes have been widely exploited in Mexico, but
Al nopal en México se le reconocen 377 especies del género Opuntia de la familia Cactaceae, de las cuales aproximadamente el $50 \%$ de ellas son aprovechadas de forma artesanal o industrial, el resto de las especies se encuentran de forma silvestre, siendo aprovechadas solamente por el método de recolección sin tener un manejo de aprovechamiento adecuado. Se estima que, únicamente 15 especies son utilizadas como forraje. A nivel internacional, el principal productor es Brasil, seguido de Sudáfrica, México y Túnez. En México, los principales Estados productores, en orden de importancia, son: Oaxaca, Jalisco, San Luis Potosí, Zacatecas, Puebla, México, Hidalgo y Morelos, se estima que en México la superficie cultivada es de aproximadamente 150 $000 \mathrm{ha}$, los rendimientos promedio son cercanos a $20.5 \mathrm{t} \cdot \mathrm{ha}^{-1}$ aunque en algunos casos se llegan a tener rendimientos de hasta de $50 \mathrm{t} \cdot \mathrm{ha}^{-1}$ (Saravia, s/f).

Se estima que el $66.2 \%$ de la superficie de México se encuentra dentro de lo que se considera clima árido y semiárido, siendo la porción centro norte la que presenta estas condiciones, los principales estados que se encuentran en esta situación son Aguascalientes, Baja California, Baja California Sur, Coahuila, Chihuahua, Durango, Guanajuato, Nuevo León, Querétaro, San Luis Potosí, Sonora, Tamaulipas y Zacatecas, la particularidad es que más del $50 \%$ de su territorio presenta las características de clima árido y semiárido (Medina, Ruiz, \& Bravo, 2004, INEGI, 2005)

En las zonas áridas y semiáridas es común que se presenten épocas de escasez de alimento para los animales, por lo que los ganaderos recurren a plantas forrajeras cultivadas, esto, con la finalidad de mantener la productividad del sistema ganadero, en estas regiones la producción de forraje es limitada debido a la poca disponibilidad de agua y escasa fertilidad del suelo, bajo esta situación, el nopal adquiere un gran valor como alimento para ganado, debido a su gran capacidad para establecerse, reproducirse y producir forraje suficiente en condiciones de escasa precipitación y baja fertilidad del suelo y así producir el forraje para el ganado permitiendo su supervivencia (de la Rosa \& Santana, 1998; Flores \& Aranda, 1997).

En las zonas semiáridas del norte de México es crítica la situación de la alimentación animal en los 
in other countries such as Brazil (semi-arid northeast) the spineless nopal cladode is used as fodder for cattle, accounting for more than 400000 ha of rainfed farmland (Cordeiro \& Gonzaga, 2003).

Solid and semi-solid fermentation has been carried out on different vegetables to increase their protein content and improve the possibilities of conserving or changing their physical characteristics, including color, odor or taste (Hesseltine, 1972). Semisolid fermentation in nopal (Opuntia spp) is carried out on cut cladodes (substrate) by adding a mixture of minerals to increase their protein content (Tabosa et al., 2003) and was adapted from the "saccharin" sugarcane technology in Cuba (Elías, Orquidea, Cordeiro, \& Quintana, 1990; Elías \& Lescano, 1993). Fodder resulting from semi-solid fermentation can be used as a feed supplement, once the amount of protein generated in the process is verified and the fodder is supplied to livestock to determine the increase in production factors such as milk and meat (Tabosa, et al.,2003; Ariosvaldo et al., 2004).

In order to generate a nopal supplement for use as fodder in the difficult drought period in Mexico's north central region, and which can be used throughout the year given the crop's perennial nature, Nopal Protein Enrichment Technology (machine and process) was developed in 2011 and validated in the 2014-2015 period. Under it, aerobic semi-solid fermentation is mechanically carried out on 1-year-old spineless nopal fractions, which provides greater efficiency in time and resources (Flores, et al., 2011; Flores et al., 2014).

This study shows the characteristics of the aerobic semi-solid fermentation process carried out in 2015 and the chemical composition results in the 1-year-old spineless nopal fractions, before and after the process, and their comparison with alfalfa (preferred fodder in the region, but with high water consumption), which allows us to recommend the use of nopal as a fodder supplement with its corresponding advantages.

\section{Materials and methods}

At the URUZA-UACh nopal storage facility in Bermejillo, Dgo., during the period from March 31 to April 22, 2015, aerobic semi-solid fermentation of $100 \mathrm{~kg}$ of nopal was carried out on three different meses de sequía a causa de la poca disponibilidad de forrajes y el alto costo de fuentes proteicas, lo que imposibilita el uso adecuado de complementos, desatendiendo los requisitos mínimos de estos nutrientes para los animales (Murillo et al., 2009). El Nopal (Opuntia spp) en este difícil periodo es ampliamente utilizado por su alto contenido de agua (70 a $90 \%$ ) a pesar de su bajo valor proteico (2.7 a 8.8 \%) (López, Fuentes, \& Rodríguez, 2003). Las ventajas del cultivo de nopal sin espinas para brote han sido ampliamente aprovechadas en México, pero en otros países como Brasil (semiárido nordestino), la penca de nopal sin espinas se usa como forraje para el ganado bovino, ocupando su cultivo en temporal más de 400000 ha (Cordeiro \& Gonzaga, 2003).

La fermentación sólida y semisólida se ha realizado en diferentes vegetales para aumentar el contenido proteico de los alimentos y para mejorar las posibilidades de conservación o cambio en las características físicas como, el color, el olor o el sabor (Hesseltine, 1972). La fermentación semisólida en nopal (Opuntia spp) se efectúa sobre pencas cortadas (substrato) con la adición de una mezcla de minerales para aumentar el contenido de proteína (Tabosa et al., 2003) y fue adaptada de la tecnología "sacarina" de la caña de azúcar en Cuba (Elías, Orquidea, Cordeiro, \& Quintana, 1990; Elías \& Lescano, 1993). Los forrajes producto de la fermentación semisólida pueden ser usados como complemento alimenticio, una vez que se compruebe la cantidad de proteína generada en el proceso, y ser suministrado al ganado para determinar el aumento en factores de producción como leche y carne (Tabosa, et al.,2003; Ariosvaldo et al., 2004).

Con el fin de generar un complemento de nopal como forraje en la difícil época de sequía, y que pueda ser utilizado todo el año dada la naturaleza perenne del cultivo, en la región centro norte de México, se desarrolló en el año 2011 y se validó en el periodo 2014-2015, la Tecnología de Enriquecimiento Proteico del Nopal (máquina y proceso) que realiza la fermentación semisólida aeróbica de fracciones de nopal anual sin espinas de manera mecanizada, lo que concede una mayor eficiencia en tiempo y recursos (Flores, et al., 2011; Flores et al., 2014)

Este estudio muestra las características del proceso de fermentación semisólida aeróbica realizado en el 
occasions (replicates) using a machine or biodigester (Figure 1) (Title No. 2641- IMPI, Mexico). The process (Title No. 339696- IMPI, Mexico) consists of cutting the 1-year-old spineless nopal cladodes, which fall fractionated into a mixing cylinder (homogenizer). As a nitrogen source, urea (1\%) and ammonium sulfate $(0.1 \%)$ were added to the substrate. Fermentation was initiated by adding $1 \%$ yeast (Sacharomyces cereviceae), by means of 8 intercalated cycles (45 minutes of motion and 30 minutes of rest) over a 10-hour period (programmed by electronic timer), from 8:00 a.m. to 6:00 p.m. The nopal fodder obtained before and after the process was sampled for dry matter analysis using the partial dry matter technique adapted from Goering \& Van Soest (1970), año 2015 y los resultados de la composición química en las fracciones de nopal anual sin espinas, antes y después del proceso, y su comparación con la alfalfa (forraje preferido en la región, pero de alto consumo de agua), lo que permite recomendar el uso de nopal como complemento forrajero con las ventajas correspondientes.

\section{Materiales y métodos}

En la bodega de Nopal de URUZA- UACh, Bermejillo, Dgo., durante el periodo del 31 de marzo al 22 de abril del 2015, se realizó por tres ocasiones diferentes (repeticiones) la fermentación semisólida aeróbica de $100 \mathrm{~kg}$ de nopal mediante una máquina o biodigestor (Figura 1) (Título No. 2641- IMPI,

Figure 1. Biodigester and nopal load

Figura 1. Biodigestor y carga de nopal

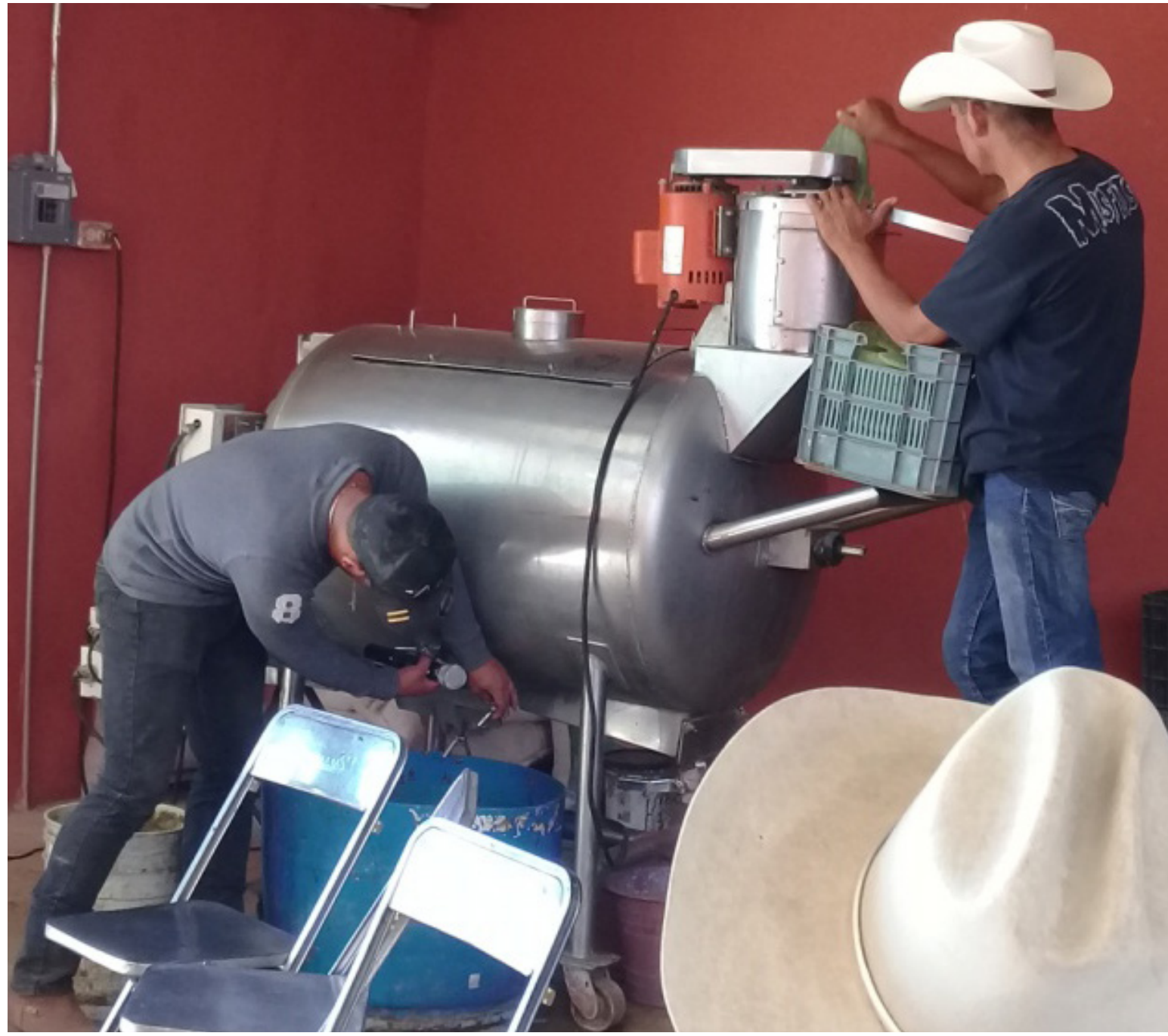


with additional modification of $105^{\circ} \mathrm{C}$ for $2 \mathrm{~h}$. Crude protein was determined according to the Official Methods of Analysis (2000) protein (crude) in animal feed technique (990.03). Metabolizable energy (ME) was determined following the technique proposed by McDonald, Edwards, Greennalgh, \& Morgan (2002) and non-fibrous carbohydrates (sugars and starch) by the method of Van Soest, Robertson, \& Lewis (1991). To compare these results with those of alfalfa (preferred fodder in the region), different samples of fresh alfalfa were taken at random from a crop adjacent to the nopal plot, and the same chemical components were mixed and determined in this mixture. Results were statistically analyzed with the SAS Program (9.1)/ GLM procedure and Tukey's multiple comparison test using a completely randomized design with three replicates of the unfermented chopped nopal (control) and fermented chopped nopal treatments. During the fermentation process, temperature (digital thermometer) and $\mathrm{pH}$ (Conductronic $\mathrm{PH} 10$ potentiometer) measurements were made of the substrate every 2 hours for 10 hours.

\section{Results and discussion}

Statistical analysis of the results of chemical components detected in nopal fractions before and after the aerobic semi-solid fermentation process showed no significant difference among replicates within each of the treatments (before and after the process), indicating that on the three spring dates when the study was carried out there was no significant climatic variation in that process, as shown by average temperature $\left(21.7 \pm 2.04{ }^{\circ} \mathrm{C}\right)$ and $\mathrm{pH}(4.35 \pm 0.04)$ data for the three dates. It should be indicated that the $\mathrm{pH}$ showed minimum variation, while the initial average fermentation temperature gradually increased as the morning progressed into the afternoon. It is important to point out that in other tests carried out in summer the temperature significantly affected the fermentation process (data not shown), being important to identify the time during the day or night that the temperature does not exceed $28^{\circ} \mathrm{C}$ or is lower than $22^{\circ} \mathrm{C}$. The ideal situation is to have a controlled climate where optimal population growth of the yeast occurs with a temperature of $25.5 \pm 3.5^{\circ} \mathrm{C}$ and an acid pH of $4.5 \pm 0.5$ (García, 1995).
México) siguiendo el proceso (Título No. 339696IMPI, México), que consiste en el corte del cladodio o penca anual de nopal sin espinas, el cual cae fraccionado al cilindro mezclador (homogenizador). A este substrato se le agregó como fuente de nitrógeno: Urea (1 \%) y Sulfato de amonio (0.1 \%) y se inició la fermentación con la adición de la levadura (Sacharomyces cereviceae) al $1 \%$, mediante 8 ciclos intercalados (45 minutos de movimiento y 30 minutos de reposo) durante 10 horas (programado mediante temporizador electrónico), de las 8:00 a 18:00 horas. Al forraje de nopal obtenido antes y después del proceso se le tomó una muestra para el análisis de: Materia Seca, usando la técnica de materia seca parcial adaptada de Goering, \& Van Soest (1970), con modificación adicional de $105^{\circ} \mathrm{C}$ por $2 \mathrm{~h}$. Proteína cruda según la técnica de Proteína (Cruda) de alimentación animal (990.03), Official Methods of Analysis, (2000). Energía metabolizable (EM) siguiendo la técnica propuesta por McDonald, Edwards, Greennalgh, \& Morgan (2002) y Carbohidratos no fibrosos (Azúcares y almidón) por el método de Van Soest, Robertson, \& Lewis (1991). Para comparar estos resultados con la alfalfa (forraje preferido en la región) se tomaron al azar diferentes muestras de alfalfa fresca de un cultivo aledaño a la parcela de nopal, se mezclaron y determinaron en esta mezcla los mismos componentes químicos. Los resultados fueron analizados estadísticamente con el procedimiento GLM del Programa SAS (9.1) y la prueba de comparación de medias de Tukey, en un diseño completamente al azar con tres repeticiones del tratamiento nopal picado sin proceso (Testigo) y nopal picado fermentado. Durante el proceso de fermentación se realizaron mediciones de temperatura (termómetro digital) y del pH (Potenciómetro Conductronic PH10) del sustrato, cada 2 horas por 10 horas.

\section{Resultados y discusión}

El análisis estadístico de los resultados de los componentes químicos detectados en fracciones de nopal (sustrato) antes y después del proceso de fermentación semisólida aeróbica, no mostró diferencia significativa entre las repeticiones dentro de cada uno de los tratamientos (antes y después 
In the analysis of the resulting chemical components, the highly significant difference between treatments, before and after fermentation (Table 1), stands out in an important way, which can be seen by the notable increase in crude protein due to the fermentation effect, being almost five times higher than the normal protein content of unfermented nopal (control). In contrast, there was a drastic decrease in the content of non-fibrous carbohydrates (sugars and starch) of almost $50 \%$ in the fermented nopal fractions with respect to the unfermented ones, attributable to the consumption of these carbohydrates by the population growth of the unicellular fungus or yeast; it is thought that when oxygen is present this population grows efficiently as a result of the carbohydrates and nitrogen in the medium to produce biomass and $\mathrm{CO}_{2}$ (Hernández, 2003). This is clearly seen in Figure 2, where the decrease in carbohydrates has a direct relationship with the increase in protein when comparing the unfermented nopal (control) with the fermented nopal.

In terms of metabolizable energy, there was also a statistically significant difference, which, even if numerically seen as minimal, is very important given its value as fodder since the amount obtained from fermented nopal ( $\left.2.64 \mathrm{Mcal} \cdot \mathrm{kg}^{-1}\right)$ exceeds that of pasture $\left(2.08 \mathrm{Mcal} \cdot \mathrm{kg}^{-1}\right)$ and is the same as alfalfa (2.64 Mcal $\left.\cdot \mathrm{kg}^{-1}\right)$, according to data reported by Felker (2003); in this study although alfalfa had a slightly lower value, it was statistically similar to fermented nopal. Regarding dry weight, the nopal before and del proceso), lo que indica que en las tres fechas de primavera en que se realizó el estudio no se presentó variación climática importante en dicho proceso, con datos de temperatura promedio $\left(21.7 \pm 2.04{ }^{\circ} \mathrm{C}\right.$ ) y $\mathrm{pH}(4.35 \pm 0.04)$ en las tres fechas, en ello se debe indicar que el $\mathrm{pH}$ presentó una mínima variación, en tanto que la temperatura inicial promedio de fermentación fue aumentando paulatinamente conforme avanzó la mañana hasta la tarde. Es importante destacar que, en otras pruebas realizadas en verano, la temperatura afectó significativamente el proceso de fermentación (datos no mostrados), siendo importante vigilar el tiempo durante el día o la noche que la temperatura no rebase los $28^{\circ} \mathrm{Co}$ sea inferior a los $22{ }^{\circ} \mathrm{C}$. Lo ideal es contar con clima controlado donde se dé un crecimiento óptimo de población de la levadura con una temperatura de $25.5 \pm 3.5^{\circ} \mathrm{C}$ y un pH ácido de $4.5 \pm 0.5$ (García, 1995).

En el análisis de los componentes químicos resultantes destaca de manera importante, la diferencia altamente significativa entre los tratamientos, antes y después de la fermentación (Cuadro 1), lo que se aprecia por el notable aumento de proteína cruda por efecto de la fermentación, casi cinco veces superior al contenido normal de la proteína del nopal sin fermentar (testigo), en contraposición se encontró una drástica disminución en el contenido de carbohidratos no fibrosos (azúcares y almidón) de casi la mitad en las fracciones de nopal fermentado con respecto al nopal sin proceso, lo que se atribuye al consumo de dichos carbohidratos por el crecimiento de la población del hongo unicelular o levadura, en ello se considera que cuando el oxígeno

Table 1. Average chemical components of nopal fractions before and after the fermentation process and of alfalfa Cuadro 1. Componentes químicos promedio de fracciones de nopal antes y después del proceso de fermentación y de alfalfa

\begin{tabular}{|c|c|c|c|}
\hline Component/Componente & $\begin{array}{l}\text { Before*/ } \\
\text { Antes* }\end{array}$ & $\begin{array}{c}\text { After*/ } \\
\text { Después* }\end{array}$ & Alfalfa* \\
\hline Crude Protein (\% D.M.)/Proteína Cruda (\% M.S.) & $7.08^{b}$ & $33.52^{\mathrm{a}}$ & $25.8^{a}$ \\
\hline $\begin{array}{l}\text { Non-fibrous Carbohydrates (\% D.M.)/ } \\
\text { Carbohidratos No Fibrosos (\% M.S.) }\end{array}$ & $55.03^{a}$ & $25.77^{b}$ & $27.6^{b}$ \\
\hline $\begin{array}{l}\text { Metabolizable Energy }\left(\text { Mcal } \cdot \mathrm{kg}^{-1}\right) / \\
\text { Energía Metabolizable }\left(\text { Mcal } \cdot \mathrm{kg}^{-1}\right)\end{array}$ & $2.31^{\mathrm{b}}$ & $2.64^{\mathrm{a}}$ & $2.58^{a}$ \\
\hline Dry Matter (\%) / Materia Seca (\%) & $7.95^{\mathrm{a}}$ & $7.81^{a}$ & $30.6^{a}$ \\
\hline
\end{tabular}

*Different letters between figures in the same row indicate significant difference at the level $a=0.05$ /

* Letras diferentes entre cifras de la misma hilera indican diferencia significativa al nivel $a=0.05$ 
Arnoldo Flores Hernández, Fco. Javier Macías Rodríguez, Cesar Meza Herrera, Gabriel García Herrera , Oscar Esquivel Arriaga, Jorge Ortiz Salazar , Cristóbal Hernández Bautista

Figure 2. Relationship between crude protein and non-fibrous carbohydrates, before and after fermentation* Figura 2. Relación proteína cruda y carbohidratos no fibrosos, antes y después de la fermentación*

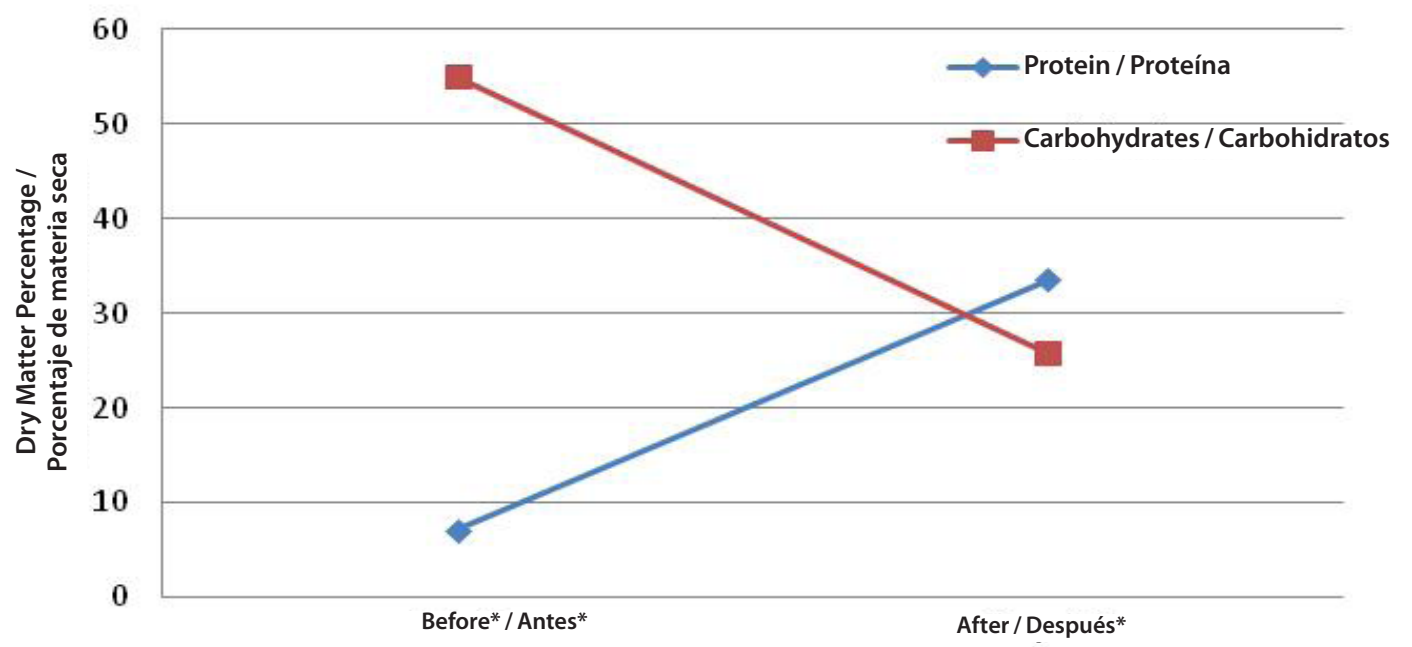

after the fermentation process showed no significant difference, which is desirable since crude protein and non-fibrous carbohydrates are expressed in relation to dry weight. However, this factor also impacts on the comparison with other fodders as described below for alfalfa, which is the preferred fodder of ranchers in the central-north regions of Mexico.

The results of the analysis of fresh alfalfa (Table 1) show that the content of non-fibrous carbohydrates is similar to that of fermented nopal; moreover, the percentage of crude protein is statistically lower than in fermented nopal and is significantly higher in dry weight (Figure 3). However, it should be considered that protein is expressed based on crop dry weight, so that even though the fermented nopal is higher in percentage of protein it is lower in terms of the amount of protein per kilogram of alfalfa (Figure 4). That is, on average, in 100 grams of fresh fermented nopal, 2.68 grams are protein ( 1 kilogram $=26.8$ grams), while in 100 grams of fresh alfalfa 7.74 grams are protein (1 kilogram $=77.4$ grams). However, nopal has competitive advantages related to water consumption and crop yield, since while nopal requires an annual water depth of $60 \mathrm{~cm}$ (Orona, Flores, \& Rivera, 2000), alfalfa has annual consumption in the order of $188 \mathrm{~cm}$ (gravityfed irrigation) to $165 \mathrm{~cm}$ (sprinkler irrigation) (Moreno, García, \& Faz, 2000). Regarding nopal yield, an average production in fresh weight of $160 \mathrm{t}$ per year is reported, considering eight está presente esta población crece eficientemente a partir de los carbohidratos y nitrógeno del medio para producir la biomasa y el $\mathrm{CO}_{2}$ (Hernández, 2003). Lo anterior se aprecia claramente en la Figura 2, donde la disminución de carbohidratos tiene una relación directa con el aumento de proteínas comparando el nopal sin fermentar (Testigo) con el nopal fermentado.

En cuanto a la energía metabolizable también se presentó una diferencia estadísticamente significativa, la que, aun cuando se aprecie numéricamente como mínima, es mucho muy importante dado su valor como forraje ya que la cantidad obtenida del nopal fermentado $\left(2.64 \mathrm{Mcal} \cdot \mathrm{kg}^{-1}\right)$, supera al pastizal (2.08 Mcal $\cdot \mathrm{kg}^{-1}$ ) y es igual que la alfalfa (2.64 Mcal $\cdot \mathrm{kg}^{-1}$ ) según datos reportados por Felker (2003), en este estudio aunque la alfalfa presentó un valor ligeramente menor fue estadísticamente similar al nopal fermentado.

En cuanto al peso seco, el nopal antes y después del proceso de fermentación no presentó diferencia significativa, lo que resulta deseable ya que la proteína cruda y los carbohidratos no fibrosos se expresan en relación con el peso seco. No obstante, este factor, también impacta en la comparación con otros forrajes como a continuación se describe para la alfalfa, que es el forraje predilecto del ganadero en las regiones del centro-norte de México.

Los resultados del análisis de la alfalfa fresca (Cuadro 1) muestran que el contenido de los 
Figure 3. Percentage (dry weight basis) of crude protein and dry matter of nopal before and after fermentation* vs. alfalfa*

Figura 3. Porcentaje (base peso seco) de proteína cruda y materia seca de nopal antes y después de la fermentación* vs. alfalfa*

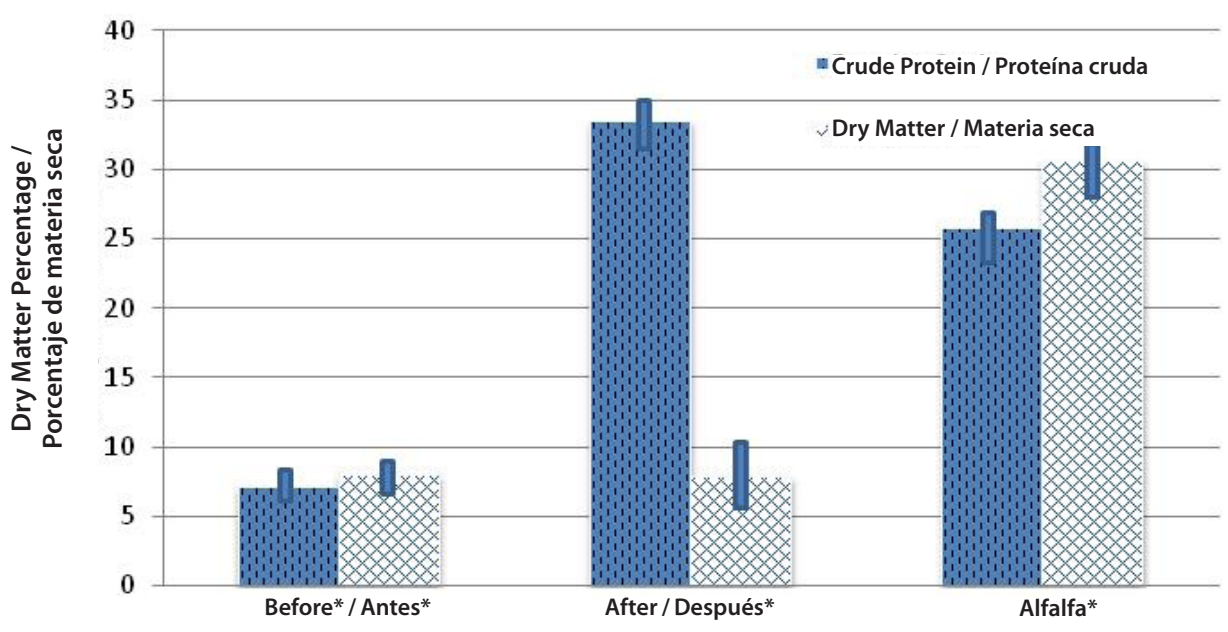

Figure 4. Protein content before and after fermentation* of nopal vs. alfalfa* per kg fresh weight . Figura 4. Contenido de proteína antes y después de la fermentación* de nopal vs. alfalfa* por kg de peso fresco.

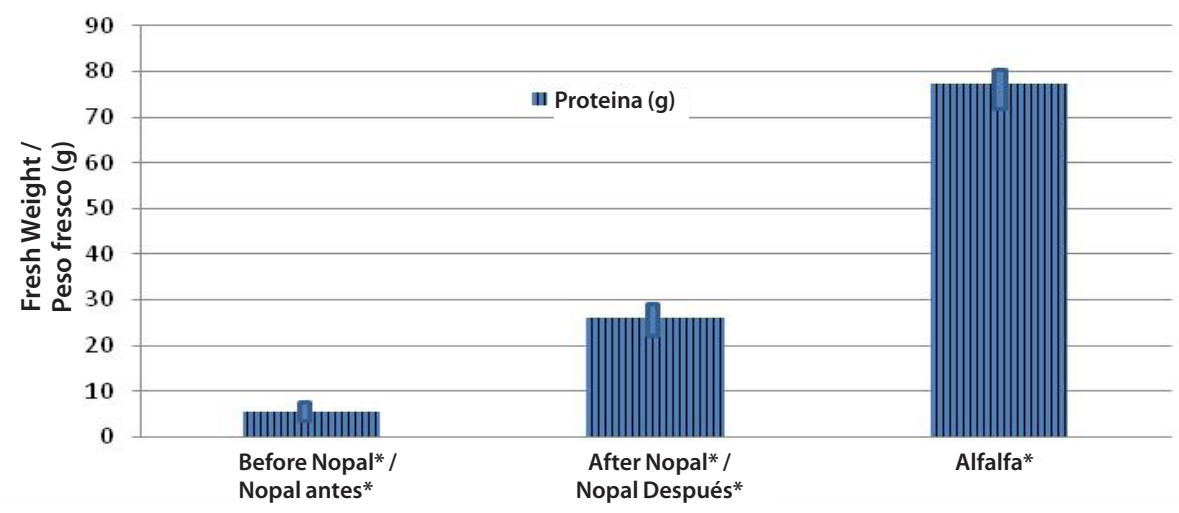

months of production (production ceases during months with an average temperature lower than $25^{\circ} \mathrm{C}$ ) (Flores et al., 2007), while the region's alfalfa yields range from 67 to 81 t.year ${ }^{-1}$ (Ríos et al., 2008).

The technology (machine and process) was validated at the producer's premises in four regions: Morelos, Zac., Cuatrocienegas, Coah., Gómez Palacio, Dgo., and Durango, Dgo., in each of them with a daily process that lasted three months. Results were very acceptable since the producer proved to himself that the mechanized process represents a saving in time and resources, in addition to the notable increase in average crude protein (6 to $30 \%, D . M$.) when the temperature was favorable and, above all, its effect on live weight gain and improvement of the animal's body condition compared to the usual diet. The carbohidratos no fibrosos es similar al nopal fermentado, el porcentaje de proteína cruda es estadísticamente inferior a este nopal procesado y es superior significativamente en el peso seco (Figura 3). No obstante, se debe considerar que la proteína se expresa con base en el peso seco del cultivo, de tal modo que aun cuando el nopal fermentado sea superior en porcentaje de proteína es inferior en cuanto a la cantidad de proteína por kilogramo de alfalfa (Figura 4). Es decir, que, en promedio, en $100 \mathrm{gr}$ de nopal fresco fermentado, $2.68 \mathrm{gr}$, son proteína ( 1 kilogramo $=26.8 \mathrm{gr}$ ), mientrasqueen $100 \mathrm{grdealfalfa}$ fresca $7.74 \mathrm{gr}$ son proteína ( 1 kilogramo $=77.4 \mathrm{gr}$ ). Sin embargo, las ventajas competitivas del nopal son en: Consumo de agua y Rendimiento del cultivo, ya que mientras el nopal requiere de una lámina 
problem detected was the variation in the ambient temperature condition, based on the region and time of study, which resulted in deficiencies in fermentation (yeast growth) and lower protein content and metabolizable energy, which was also reflected in the higher content of non-fibrous carbohydrates in the nopal substrate once fermented.

In their practical experience with sheep, Sabag and Ibarra' (2018) found that including protein-enriched nopal (Table 2), produced by means of the process mentioned above, in the diet of non-productive sheep increased their daily weight gain (250 $\mathrm{gr}^{-}$day $\left.^{-1}\right)$, which had not happened with the typical diet offered to them before including the enriched nopal, a result that pleased the producer so much that he currently includes enriched nopal in the diet offered to his entire flock of sheep, regardless of the stage of development in which they are in; to date, the sheep have not shown any adverse reactions. It should be noted that these producers are carrying out nopal fermentation in a low-tech manner (Figures 5 and 6), i.e. without the fermentation equipment mentioned in this paper and using uncultivated wild nopal anual de agua de $60 \mathrm{~cm}$ (Orona, Flores, \& Rivera, 2000), la alfalfa presenta consumos anuales en el orden de $188 \mathrm{~cm}$ (Riego por agua rodada) a $165 \mathrm{~cm}$ (Riego por aspersión) (Moreno, García, \& Faz, 2000). En cuanto al rendimiento en nopal se reporta una producción promedio en peso fresco de $160 \mathrm{t}$ anuales considerando ocho meses de producción "Meses con temperatura media menor a $25^{\circ} \mathrm{C}$ cesa la producción" (Flores et al., 2007), mientras que en alfalfa se reportan rendimientos en la región de 67 a 81 t.año ${ }^{-1}$ (Ríos et al., 2008).

La tecnología (máquina y proceso) fue validada en el predio del productor de cuatro regiones: Morelos, Zac., Cuatrocienegas, Coah., Gómez Palacio, Dgo., y Durango, Dgo., en cada una de ellas con un proceso diario durante tres meses, con resultados muy aceptables, ya que el productor comprobó por sí mismo que el proceso mecanizado representa un ahorro en tiempo y recursos, además del evidente incremento de proteína cruda del 6 al 30 \% (M.S.) promedio cuando la temperatura fue favorable $y$, sobre todo, su efecto en la ganancia de peso vivo y mejora de la condición corporal del animal en

Table 2. Laboratory results* of the nopal and typical diet used by the producer in Jerez, Zac., dated 15 July 2018 Cuadro 2. Resultados de laboratorio* del nopal y dieta típica usada por el productor en Jerez, Zac., de fecha 15 de julio de 2018

\begin{tabular}{|c|c|c|c|c|c|c|}
\hline $\begin{array}{l}\text { Product / } \\
\text { Producto }\end{array}$ & $\begin{array}{c}\text { Crude } \\
\text { protein } \\
\text { (\% DM) / } \\
\text { Proteína } \\
\text { cruda } \\
\text { (\% MS) }\end{array}$ & $\begin{array}{c}\text { Acid detergent } \\
\text { fiber } \\
\text { (\% DM) / } \\
\text { Fibra } \\
\text { detergente } \\
\text { acido } \\
\text { (\% MS) }\end{array}$ & $\begin{array}{c}\text { Neutral } \\
\text { detergent fiber } \\
\text { (\% } \% \text { DM) / } \\
\text { Fibra } \\
\text { detergente } \\
\text { neutra } \\
\text { (\% MS) }\end{array}$ & 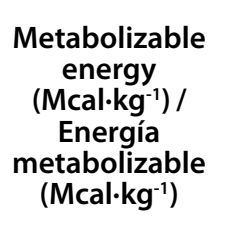 & $\begin{array}{c}\text { Ash (\% DM) / } \\
\text { Cenizas } \\
\text { (\% MS) }\end{array}$ & $\begin{array}{c}\text { Dry matter } \\
(\%) / \\
\text { Materia seca } \\
(\%)\end{array}$ \\
\hline $\begin{array}{l}\text { Unfermented nopal / } \\
\text { Nopal sin fermentar }\end{array}$ & 5.46 & 22.56 & 30.06 & 2.26 & 25.64 & 7.24 \\
\hline $\begin{array}{l}\text { Fermented nopal / } \\
\text { Nopal fermentado }\end{array}$ & 19.09 & 23.36 & 24.08 & 2.81 & 25.84 & 8.21 \\
\hline $\begin{array}{l}\text { Typical diet / } \\
\text { Dieta típica }\end{array}$ & 15.03 & 27.6 & 36 & 2.65 & 7.9 & 61.53 \\
\hline
\end{tabular}

*Agro Lab México, S.A. de C.V. Inde 735. 4ª Etapa, Parque Industrial Lagunero, Gómez Palacio, Dgo. C.P. 35078. Email: forrajes@ agrolabmexico.com

'Personal communication from Oscar Sabag Martínez and veterinarian Luis Ernesto Ibarra de la Torre. July 2018. Rancho "El Manicomio" Jerez de García Salinas, Zac. 
Figure 5. Chopping of one-year-old cladodes Figura.

Figura 5. Pencas de un año y picado de las mismas.

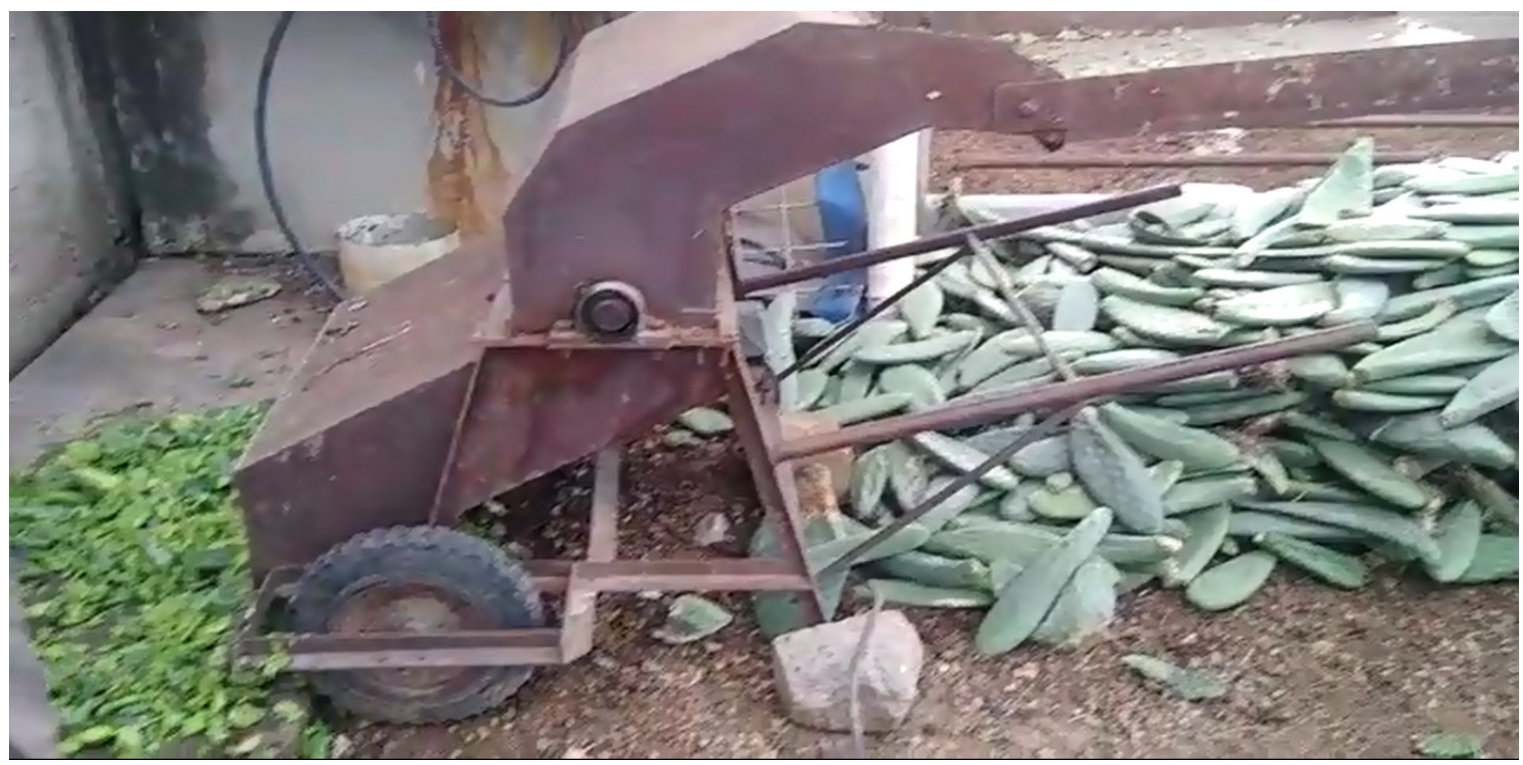

Figure 6. Low-tech biodigester equipment for nopal fermentation Figura 6. Equipo biodigestor rústico para fermentación del nopal.

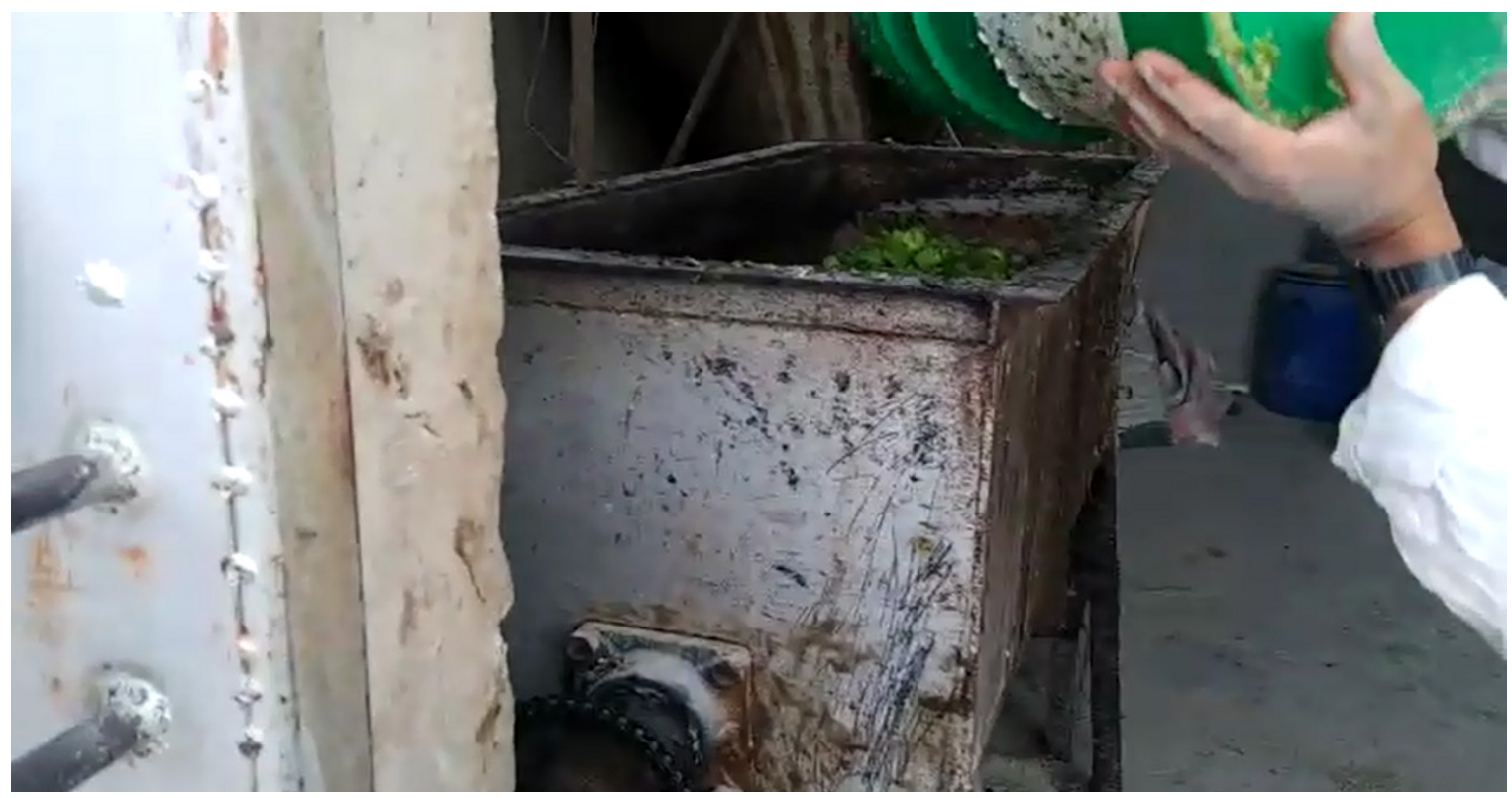

and varieties nct considered as fodder, although in October 2018 they began using nopal considered as fodder (copena 4 variety), estimating a production of $200 \mathrm{t} \cdot$ ha.year ${ }^{-1}$ of cladode.

\section{Conclusions}

1. Fermentation of nopal substrate yielded a significant increase in crude protein from 7 to $33 \%$ and metabolizable energy from 2.3 to comparación con la dieta habitual. El problema detectado fue la variación en la condición de temperatura ambiente, según la región y época de estudio, lo que originó en su caso, deficiencias en la fermentación (crecimiento de la levadura), menor contenido de proteína y energía metabolizable, lo que se reflejó también en el mayor contenido de carbohidratos no fibrosos en el sustrato del nopal una vez fermentado. 
2.67 Mcal. $\mathrm{kg}^{-1}$, as well as a drastic decrease in the percentage of non-fibrous carbohydrates from 48.9 to $26.4 \%$, compared to the unfermented nopal substrate (control).

2. Fermented nopal has a higher percentage of crude protein than alfalfa, but when compared in terms of dry weight, alfalfa's protein content was higher than that of nopal. However, nopal's competitive advantages are considered to be its greater water consumption efficiency and production compared to alfalfa.

3. The crude protein and metabolizable energy values of fermented nopal are favorable for its use as an animal feed supplement.

4. The practical experience of producers indicates that protein-enriched nopal is a viable and safe feed source for livestock production.

\section{Acknowledgments}

The authors wish to thank the following for their support: the Institute for Innovation in Biosystems and Sustainable Development in Arid Zones (IIBIODEZA) through the project Validation of Nopal (Opuntia spp) Protein Enrichment Technology (Key: 17019 DTT), administered by the General Directorate of Research and Graduate Studies of Chapingo Autonomous University, and the State of Durango's Science and Technology Council (COCyTED) through the project Transfer of Nopal (Opuntia spp) Protein Enrichment Technology in the Poanas region, Dgo.

\section{References / Referencias}

End of English version

Anaya Pérez, M. A. (2003). Historia del uso de Opuntia como forraje en México. En El nopal (Opuntia spp.) Como Forraje. Editores Candelario Mondragón-Jacobo y Salvador Pérez-González. Estudio FAO Producción y Protección Vegetal 169. ISSN 1014-1227, ISBN 92-5-304705-4. Organización de las Naciones Unidas Para la Agricultura y la Alimentación. Roma, 2003

Ariosvaldo N. M., Suassuna A., Goncalves P. S., Furtado, D. D., Flores V., C..., De Melo O. M. (2004). Enriquecimiento proteico de palma forrajera (Opuntia ficus indica Mill.) Por procesos
En la experiencia práctica con ovinos Sabag e lbarra' (2018), se encontró que, al incluir en la dieta de nopal enriquecido con proteína (Cuadro 2), mediante el proceso mencionado anteriormente, aplicado a borregas de desecho, estas incrementaron su ganancia diaria de peso (250 gr·día $\left.{ }^{-1}\right)$, cosa que no había sucedido con la dieta típica que se les ofrecía antes de incluir el nopal enriquecido, situación que agradó al productor por lo que actualmente incluye nopal enriquecido en la dieta que oferta a todo el rebaño de ovinos independientemente de la etapa de desarrollo en que se encuentren, a la fecha, el ganado no ha presentado reacciones adversas. Cabe mencionar que, estos productores están realizando de manera rústica la fermentación del nopal (Figuras 5 y 6), es decir sin el equipo fermentador que se menciona en este escrito y utilizando nopal silvestre no cultivado, ni de variedades consideradas forrajeras, aunque a partir del mes de octubre de 2018 empezaron a utilizar nopal considerado forrajero de la variedad copena 4, estimándose una producción de 200 t.ha·año-1 de penca.

\section{Conclusiones}

1. En la fermentación en sustrato de nopal se registró un aumento significativo de proteína cruda del 7 al $33 \%$, energía metabolizable del 2.3 a 2.67 Mcal. $\mathrm{kg}^{-1}$ y una drástica disminución del porcentaje carbohidratos no fibrosos 48.9 a $26.4 \%$, comparado con el sustrato de nopal sin fermentar (Testigo).

2. El nopal fermentado aun cuando presenta un mayor porcentaje de proteína cruda en relación con la alfalfa, una vez referido al peso seco, el contenido de proteína de la alfalfa fue mayor a la del nopal. No obstante, se considera que las ventajas competitivas del nopal se centran en su mayor eficiencia en el consumo de agua y producción en comparación con la alfalfa.

3. Los valores de proteína cruda y energía metabolizable del nopal fermentado son favorables para su uso como complemento en la alimentación animal.

4. La experiencia práctica de productores indica

'Comunicación personal del Sr. Oscar Sabag Martínez y MVZ. Luis Ernesto Ibarra de la Torre. Julio de 2018. Rancho "El Manicomio" Jerez de García Salinas, Zac. 
biotecnológicos probados en Ovinos Santa Inés. 41 a. Reunión Anual de la Soc. Brasileira de Zootecnia. Campo Grande, Brasil.

Cordeiro dos Santos, D., \& Gonzaga de Albuquerque,

S. (2003). Opuntia como forraje en el noreste semiárido del Brasil. En Mondragón-Jacobo, C y Pérez-González, S. (Eds.). El nopal (Opuntia spp.) Como Forraje. Estudio FAO- producción y protección vegetal,169: Organización de las Naciones Unidas para la Agricultura y la Alimentación. Roma Italia.

de la Rosa H., P., \& Santana A., D. (1998). El Nopal: usos, manejo agronómico y costos de producción. Ed. Universidad Autónoma de Chapingo. Chapingo, México. pp. 129-145.

Elías, A., Orquidea, L. P., Cordeiro, J., \& Quitana, L. (1990). Reseña descriptiva sobre el desarrollo de una tecnología de enriquecimiento proteico en la caña de azúcar-fermentación en estado sólido (Saccharina). Rev. Cubana de Ciencia Agric., 24:1, 1-12p.

Elías, A., \& Lezcano, O. (1993). Efecto de la fuente de N y algunos factores de crecimiento en la población de levaduras que se establece en la Producción de Saccharina. Rev. Cubana de Cienc. Agric. 27:227.

Felker, P. (2003). La utilización de Opuntia como forraje en los Estados Unidos de América. En: Mondragón-Jacobo, C. y Pérez-González, S. 2003. El nopal (Opuntia spp.) Como Forraje. Estudio FAO- producción y protección vegetal, 169: 344356, Organización de las Naciones Unidas para la Agricultura y la Alimentación. Roma Italia

Flores V., C. A., \& Aranda O. G. (1997). El nopal como forraje en México. En Vázquez A., R., C. Gallegos V., N. E.Treviño H. y Díaz T.Y. (compiladores) Memorias del VII Congreso Nacional y V Congreso Internacional Sobre Conocimiento y Aprovechamiento del Nopal. 15 al 19 de Septiembre, Monterrey, N.L., México. Facultad de Agronomía-UANL y FAO.

Flores, H. A., Macías, R. F. J., Esparza, I., E., Cantú, B. E., \& Gámez, A. M., Madinaveitia, R. H., Quiñones, Z. A. (2011). Enriquecimiento proteico del nopal (Opuntia spp) como forraje. UACH-COCYTEDFIRA-URUZA. $22 \mathrm{p}$.

Flores-Hernández, A., Macías-Rodríguez, F. J., Ortega Sánchez, J. L., Esquivel Arriaga, O., García Herrera, G., \& Murillo-Amador, B. (2014). 3.3.3. Tecnología que el nopal enriquecido con proteína es una fuente viable de alimentación sin riesgos para la producción de ganado,

\section{Agradecimientos}

Al Instituto de Innovación en Biosistemas y DesarroIlo Sustentable en Zonas Áridas (IIBIODEZA) a través del proyecto: Validación de la Tecnología de Enriquecimiento proteico de Nopal (Opuntia spp) Clave: 17019 DTT, de la Dirección General de Investigación y Posgrado de la Universidad Autónoma Chapingo, y al Consejo Estatal de Ciencia y Tecnología del Estado de Durango (COCyTED) a través del proyecto: Transferencia de la tecnología de enriquecimiento proteico de nopal (Opuntia spp) en la región de Poanas, Dgo.

Fin de la versión en español

de enriquecimiento proteico como medio para aumentar la calidad del nopal como forraje. En: Desarrollos de Ingeniería Agrícola en América Latina. Depto. Ing. Agr. Universidad Autónoma Chapingo, México. 1511-1518 p.

Flores-Hernández, A., Orona-Castillo, I., TrejoCalzada, R., Arreola-Ávila, J., Murillo-Amador G.,.., García-Hernández, J. L. (2007). Tecnología para la producción de nopal (Opuntia spp.) bajo las condiciones extremas del norte de México. XVII Congreso Nacional de Ingeniería Agrícola AMIA2007:1-15p

García Cortés, V. (1995). Introducción a la Microbiología. 2da. Ed. Universidad Estatal a Distancia. Costa Rica: 108-116p.

Goering, H. K., \& Van Soest P., J. (1970). Forage Fiber Analysis. USDA Agricultural Research Service. Handbook number 379. U.S. Dept. of Agriculture. Superintendent of Documents, US Government Printing Office, Washington D.C. 20402.

Instituto Nacional de Estadística, Geografía e Informática (INEGI). (2005). Anuario estadístico por entidad federativa. Edición 2005. Aguascalientes, Ags. México. 
Arnoldo Flores Hernández, Fco. Javier Macías Rodríguez, Cesar Meza Herrera, Gabriel García Herrera , Oscar Esquivel Arriaga, Jorge Ortiz Salazar ,

Cristóbal Hernández Bautista

Hernández Peñaranda, A. (2003). Microbiología Industrial. Universidad Estatal a Distancia. Costa Rica. 177-183 p.

Hesseltine C. W. (1972). Solid State Fermentations. Biotechnol .and Bioeng. 14:517 - 532.

López González, J. J., Fuentes Rodríguez, J. M., \& Rodríguez Gámez, A. (2003). Producción y uso de Opuntia como forraje en el centro-norte de México. En Mondragón-Jacobo, C y PérezGonzález, S. 2003. El nopal (Opuntia spp.) Como Forraje. Estudio FAO- producción y protección vegetal,169:213-240. Organización de las Naciones Unidas para la Agricultura y la Alimentación. Roma Italia.

Medina G., G., Ruiz Corral J., A., \& Bravo L., A. G. (2004). Definición y clasificación de la sequía. En: Bravo L., A. G.; H. Salinas G. y A. F. Rumayor R. (Eds.). Sequía: Vulnerabilidad, impacto y tecnología para afrontarla en el norte centro de México. Libro Técnico No 4. INIFAP-SAGARPA, México.

McDonald, P.; Edwards, R. A.; Greennalgh, F. J. D., \& Morgan, C. A. (2002). Digestibility.AnimalNutrition. En Evaluation of Foods (SixthEdition).Pearson. Prentice-Hall

Moreno Díaz, L., García Arellano, D., \& Faz- Contreras, R. (2000). Manejo del riego en la alfalfa. En: Producción y utilización de la alfalfa en la zona norte de México. SAGAR- INIFAP- CIRNOC- CELALA Torreón- Matamoros, Coah. Libro Técnico No. 2-73p

Murillo-Amador, B., López-Aguilar, R., GarcíaHernández, J. L., Nieto-Garibay, A., Troyo-Diéguez, E., Ávila-Serrano,..., Plascencia-Jorquera, A.
(2009). Cultivos Forrajeros Alternativos para Zonas Áridas y Semiáridas. Foro: Ciencia, tecnología e innovación para el desarrollo. Rev. El sudcaliforniano, Año 1, No. 21.

Official Methods of Analysis. (2000). 17 $7^{\text {th }}$ edition. Association of Official Analytical Chemists, EUA.

Orona, C. I., Flores, H. A., \& Rivera, G. M. (2000). Manual para el establecimiento y manejo del nopal verdura bajo riego por goteo en la Comarca Lagunera. CENID RASPA-INIFAP, Gómez Palacio, Durango, México. 18 p.

Ríos Flores, J. L., Ruiz Torres, J., Cisneros Vázquez, J. M., Cantú Brito, J. E., Torres Moreno, M., \& Quiñones A., M. (2008). Producción, productividad y rentabilidad de alfalfa (Medicago sativa) irrigada por bombeo en la Laguna de 1990 a 2005. Revista Chapingo Serie Zonas Áridas. 2008. 7:145-150.

Saravia Tasayco, P. (s.f.), "Agrupamientos productivos (clúster) del nopal", en

http://www.contactopyme.gob.mx/estudios/docs/ nopal_mexico.PDF (consultado el 10 de octubre 2018)

Tabosa, J. B., Simplício, J. J., Tavares, F., Dias F., M., Farias, J., Dos santos M., S.,..., Monteiro M., C. D. (2003). Enriched Forage Cactus Meal To Feed Ruminants. IPA - Agricultural and Livestock Research Enterprise, State of Pernambuco - Brazil. Van Soest, P. J., Robertson, J. B., \& Lewis, B. A. (1991). Methods for Dietary Fiber, Neutral Detergent Fiber, and Nonstarch Polysaccharides in Relation to Animal Nutrition.J.DairyScience 74:3583-3597. 